\title{
污濁防止膜による流況制御に関する研究 STUDY OF FLOW CONTROL BY SILT CURTAIN
}

\author{
小野正順 1 - 安井章雄 2 - 有光 剛 3 - 出口一郎 4 \\ Masanobu ONO, Akio YASUI, Tsuyoshi ARIMITSU and Ichiro DEGUCHI

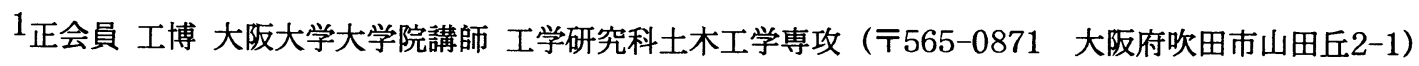 \\ 2正会員 太陽工業株式会社 \\ 3 正会員 工修 関西電力株式会社 \\ 4 正会員 工博 大阪大学大学院教授 工学研究科土木工学専攻
}

\begin{abstract}
Silt curtains are generally stretched around construction site in the coastal region to protect turbidity generated by the construction works from flowing out of the region. The hydraulic functions of silt curtain have been investigated in the two-dimensional wave tank. However, the silt curtains are stretched in a three-dimensional sea and three-dimensional effect becomes very important.

In this study, the effects of a stand-up type and a hang-down type silt curtain on the unidirectional flow are investigated through experiments in a basin. The authors also proposed numerical model for predicting flow pattern around silt curtain and examined the validity of the procedures by using experimental results.
\end{abstract}

Key Words : stand-up type silt curtain, hang-down type silt curtain, flow control, SOLA method

\section{1.はじめに}

近年，沖合人工島や海上空港建設などの海洋工事 に伴う污濁発生に対して, 周辺海域への污濁の流出 を防止するために污濁防止膜が設置される．污濁防 止膜の污濁防止効果は, (1)防止膜背後の死水領域の 形成とそれによる污濁のトラップ効果, (2)膜端部か ら発生する乱れによる污濁拡散効果などが考えられ る.いずれの効果も污濁防止膜周辺の流況と密接に 関係している. 污濁防止膜周辺の流れ場に関する研 究は，垂下式あるいは自立式の污濁防止膜をそれぞ れ単体で設置した場合の実験的研究1)がいくつか行 われている. しかしながら，最近は垂下式と自立式 の污濁防止膜を 2 重に設置される事例が増加してい る. 一方, 実海域で展張される污濁防止膜は工事区 域を囲むように設置されるため, 従来行われてきた 断面2次元の検討結果をそのまま適用することは難 しい. また，污濁は污濁防止膜設置区画内で発生す るために，污濁防止膜設置に伴う平面的な流速場け 変化が污濁の移流拡散過程に影響しているものと考 えられる。

そこで本研究では, 污濁防止膜周辺の流れ場の特
性に関する断面 2 次元的な検討として自立式単体あ るいは自立式・垂下式を併設した場合の污濁防止膜 周辺の流況特性について検討を行った。 また，平面 的な検討として污濁防止膜を平面的に設置した場合 の污濁防止膜設置区画内之区画外の流況特性につい て検討を行い, 污濁拡散防止膜設置に伴う流況制御 効果について明らかにした.

\section{2. 污濁防止膜による流況制御に関する実験}

実験は, 図-1に示す幅 $5 \mathrm{~m}$, 長さ $15 \mathrm{~m}$, 水深 $60 \mathrm{~cm}$ の振動流平面水槽を用いて行った. 断面2次元 実験の場合は, 自立式污濁防止膜（以下，自立式と 称す）と垂下式污濁防止膜（以下, 垂下式と称す） を水槽の全幅に展張し, 3次元実験の場合は図-1に 示すように水槽の中央部で側壁に沿って, 囲い込み 長さ $\mathrm{D}=4 \mathrm{~m}, 6 \mathrm{~m}$, 囲い込み幅 $\mathrm{W}=1 \mathrm{~m}, 1.5 \mathrm{~m}, 2 \mathrm{~m}$ にわ たって自立式で囲い込み, その前後に垂下式を展張 し奏験を行った。水深は $20 \mathrm{~cm}$ で一定とし, 作用さ せた定常流の最大流速Uoは $4 \mathrm{~cm} / \mathrm{s}$ である. 流速の 測定は, 断面2次元実験の場合は水槽中央部の測線 で, 3次元実験では図-1に示すように囲い込み領域 


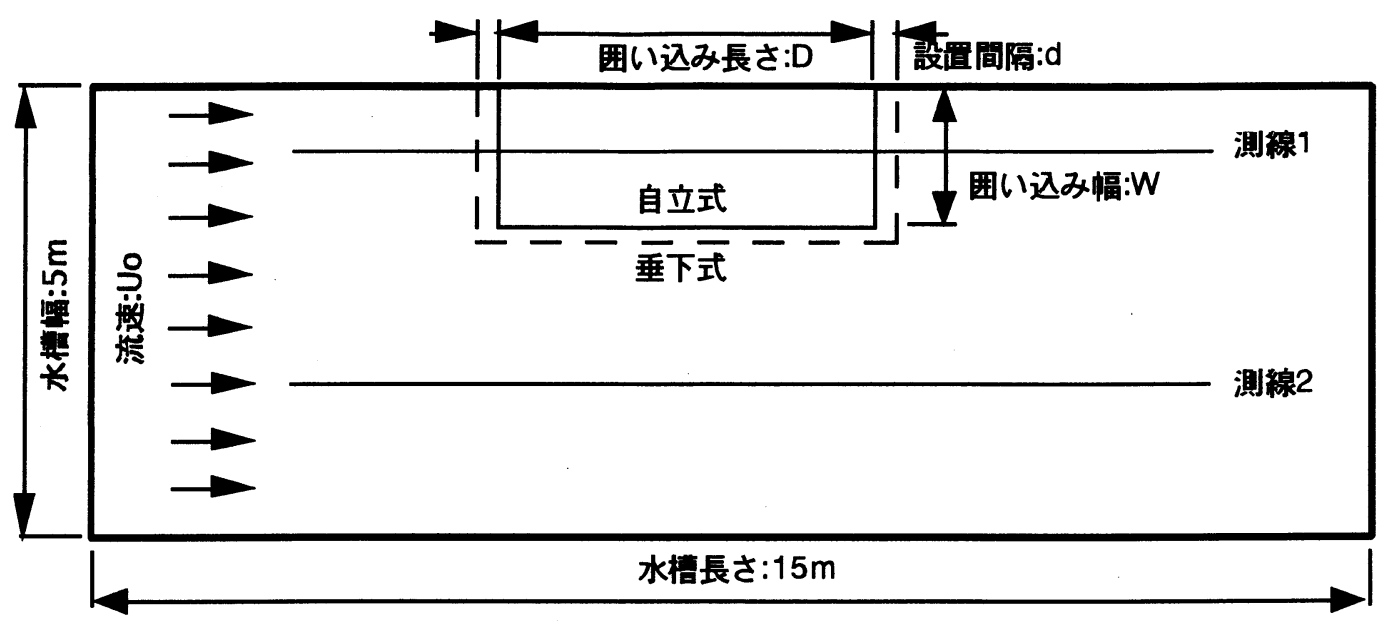

図-1＼cjkstart実験水槽及び污濁防止膜の設置方法

を含む測線 1 と囲い込夕領域を含まない測線 2 で測定 した．鈶直方向には污濁防止膜近傍では底面近傍を 含めて底面から $3.75 \mathrm{~cm}$ 間隔で 5 地点で, 膜から離れ たところでは底面近傍を含めて底面から $7.5 \mathrm{~cm}$ 間隔 で3地点を測定した.

\section{3. 污濁防止膜周辺の流況に関する数值計算}

（1）断面 2 次元流れ場に設置された膜周辺の流れに 対する数值計算

\section{a) 座標系及び計算領域}

解析モデルの座標系と計算領域を図-2に示す. 計 算は, 鈶直 2 次元場で行い. 水深hが一定の流れ場 に，膜長 $\mathrm{d}_{\mathrm{L}}, \mathrm{d}_{\mathrm{U}}$ の垂下式と自立式の污濁防止膜が, 間隔 $\mathrm{d}$ で設置されている。それぞれの污濁防止膜は 不透過である。

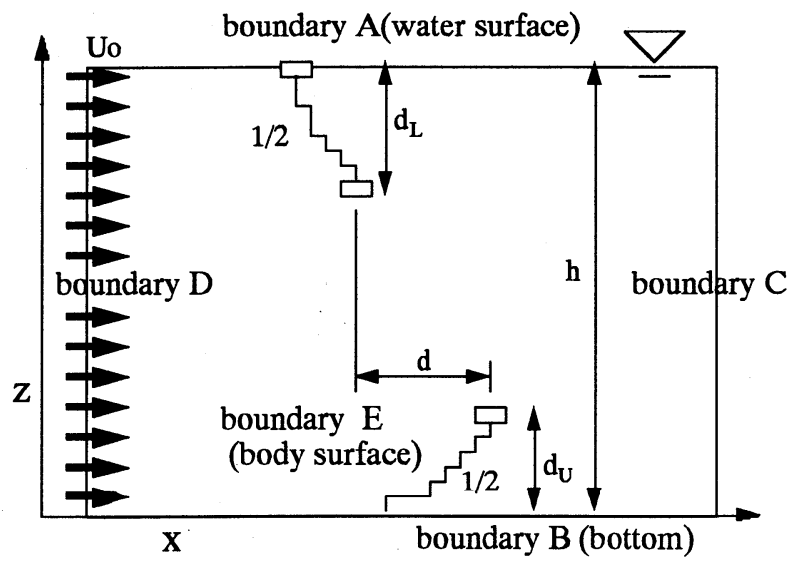

図-2 座標系及び計算領域

\section{b）基礎方程式}

計算方法は，Navier-Stokesの式を直接計算す るSOLA 法 ${ }^{2)}$ を用いた。計算に用いた基礎方程式は 次に示す連続式とNavier-Stokesの運動方程式であ
る.

$\frac{\partial u}{\partial x}+\frac{\partial w}{\partial z}=D i=0$

$\frac{\partial u}{\partial t}+\frac{\partial u^{2}}{\partial x}+\frac{\partial u w}{\partial z}=-\frac{1}{\rho} \frac{\partial p}{\partial x}+g_{x}+v\left(\frac{\partial^{2} u}{\partial x^{2}}+\frac{\partial^{2} u}{\partial z^{2}}\right)$

$\frac{\partial w}{\partial t}+\frac{\partial u w}{\partial x}+\frac{\partial w^{2}}{\partial z}=-\frac{1}{\rho} \frac{\partial p}{\partial z}+g_{z}+v\left(\frac{\partial^{2} w}{\partial x^{2}}+\frac{\partial^{2} w}{\partial z^{2}}\right)$

ここに，u,wはそれぞれ $\mathrm{x}, \mathrm{z}$ 方向の流速， $\rho$ は水の 密度, $\mathrm{g}_{\mathrm{x}}, \mathrm{g}_{2}$ は,$z$ 方向の加速度, $\nu$ は動粘性係数 ， $\mathrm{D}_{1}$ は発散を示し非圧縮性流体では0となる。

\section{c ）数值計算法及び境界条件}

数値計算は, 差分法を用いた. 運動方程式の移流 項についてはdoner差分を用い，重み定数aは0.5(0 のとき 2 次の中央差分, 1 のとき 1 次の風上差分)に設 定し，粘性項については2次の中央差分を用いた.

計算手順は，始めに(2),(3)式を用いて流速 $\mathrm{u}, \mathrm{w}$ 時間発展で求め，それぞれの時間で(1)式により発 散 $\mathrm{D}_{1}$ を計算し，発散 $\mathrm{D}_{\mathrm{i}}$ が0に収束するように圧力 $\mathrm{p}$ と 流速U,wは補正される。

境界条件は，水面 (boundary A) と海 底(boundary B)ではすべりの条件(uについては計 算領域の一つ内側の値と等しく, $\mathrm{w}=0)$ とし, 両側 方(boundary D,C)の条件は，流入側(boundary D) でu=Uo,w=0を与え，流出側(boundary C) では拘 束のない条件 $(\mathrm{u}, \mathrm{w}$ ともに計算領域の一つ内側の流速 に等しい)で与えた。構造物は物体表面の不透過条 件より，物体表面の法線方向流速を0としている。 計算領域は, 水平床で左右の境界から同じ静水圧が かかるため, $\mathrm{g}_{\mathrm{x}}, \mathrm{g}_{2}$ はとした。

（2）囲い込みによる流速低滅に関する数值計算 


\section{a) 座標系}

解析モデルは平面2次元で, 流れ方向に $\mathrm{x}$ 軸をと り，流れと直角方向に $\mathrm{y}$ 軸をとる.

\section{b）基礎方程式}

基礎方程式は, 連続式とNavier-Stokesの運動方 程式を水深方向と時間平均することで得られる質量 及び運動量保存式である.

$$
\frac{\partial}{\partial t}\{\rho(h+\eta)\}+\frac{\partial}{\partial x}\{\rho u(h+\eta)\}+\frac{\partial}{\partial y}\{\rho v(h+\eta)\}=0
$$

$$
\begin{gathered}
\frac{\partial}{\partial t}\{\rho u(h+\eta)\}+\frac{\partial}{\partial x}\left\{\rho u^{2}(h+\eta)\right\}+\frac{\partial}{\partial y}\{\rho u v(h+\eta)\}= \\
-\rho g(h+\eta) \frac{\partial \eta}{\partial x}+\frac{\partial}{\partial x}\left(k_{x} \frac{\partial u}{\partial x}\right)+\frac{\partial}{\partial y}\left(k_{y} \frac{\partial u}{\partial y}\right)-\tau_{x}
\end{gathered}
$$

$$
\begin{gathered}
\frac{\partial}{\partial t}\{\rho v(h+\eta)\}+\frac{\partial}{\partial x}\{\rho u v(h+\eta)\}+\frac{\partial}{\partial y}\left\{\rho v^{2}(h+\eta)\right\}= \\
-\rho g(h+\eta) \frac{\partial \eta}{\partial y}+\frac{\partial}{\partial x}\left(k_{x} \frac{\partial v}{\partial x}\right)+\frac{\partial}{\partial y}\left(k_{y} \frac{\partial v}{\partial y}\right)-\tau_{y}
\end{gathered}
$$

ここに，（u,v） は流下方向及び横断方向流速， $\mathrm{h}$ は水深, $\eta$ は平均水位変動量, $\mathbf{k}_{\mathrm{x}}, \mathrm{k}_{\mathrm{y}}$ は漓動粘性倸 数, $\tau_{x}, \tau_{y}$ は流下方向及び横断方向の底部せん断 力である.

\section{c）数值計算法及び境界条件}

計算は（4）〜（6）式をADI法によって差分化 し数值的に解いた。なお，污濁防止膜の影響は断面 縮小法で評価した．境界条件は，側面では不透過の 条件を, 上流側において水位と流量を与えている.

\section{4. 断面 2 次元的な流況制御の特性}

\section{（1）時間平均流速場の特性}

図-3,4は膜長 $\mathrm{d}_{\mathrm{U}}=7 \mathrm{~cm}$ の自立式単体を設置した場 合の污濁防止膜周辺の時間平均流速の分布を示し, 図-3は実験結果を図-4は計算結果をそれぞれ示す. 両図から自立式膜の上流側で上昇流が形成され，死 水領域が下流側 $100 \mathrm{~m}$ 程度まで存在していることが わかる．また，計算では水位変動を解かずに一定水 深を仮定してるため, 計算結果では水面付近での上 昇流は過小評価され，膜上方での縮流による流速増 大は過大評価されている.

図 -5,6 は, 膜長 $d_{U}=7 \mathrm{~cm}$ の自立式 ・膜長 $\mathrm{d}_{\mathrm{L}}=5 \mathrm{~cm}$ の垂下式を併設した場合の污濁防止膜周辺 の時間平均流速の分布を示し，図-5は実験結果を図 -6は計算結果をそれぞれ示す。両図から自立式単体 の場合と比較して，垂下式が設置していることによ り自立式背後の死水領域が小さくなり, 下降流速も 大きくなっていること, 垂下式の下流側で死水領域

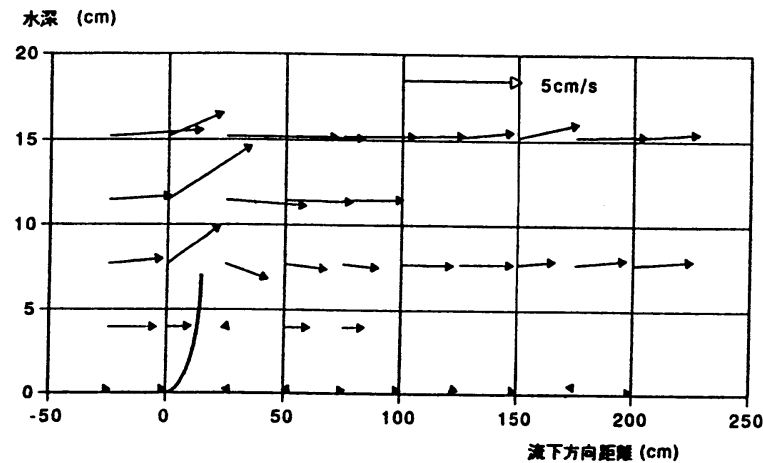

図-3 自立式単体の膜周辺の流速分布の実験結果 $\left(\mathrm{d}_{\mathrm{U}}=7 \mathrm{~cm}, \mathrm{Uo}=4 \mathrm{~cm} / \mathrm{s}\right)$

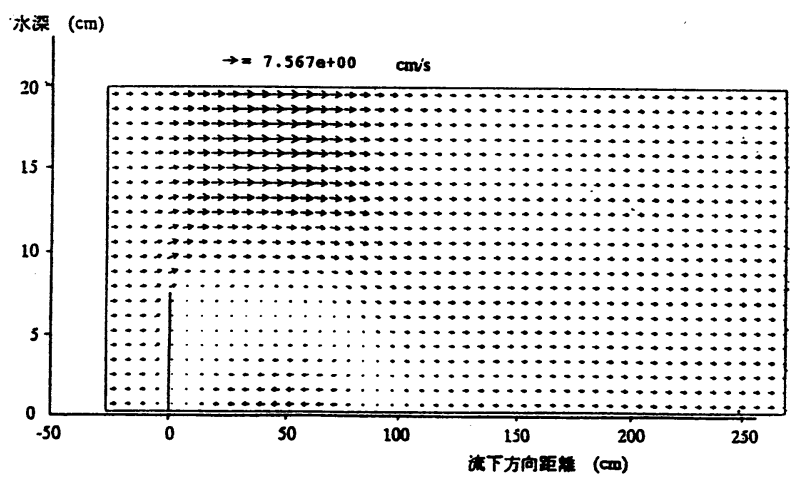

図-4 自立式単体の膜周辺の流速分布の計算結果 $\left(\mathrm{d}_{\mathrm{U}}=7 \mathrm{~cm}, \mathrm{Uo}=4 \mathrm{~cm} / \mathrm{s}\right)$

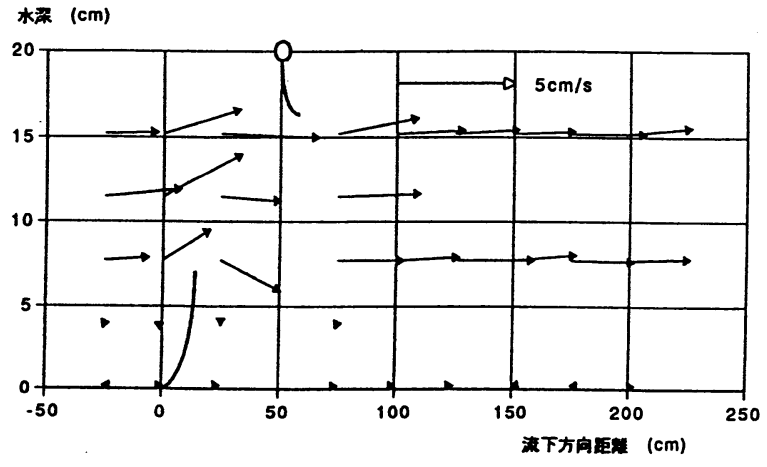

図-5 複列配置の膜周辺の流速分布の実験結果 $\left(\mathrm{d}_{\mathrm{U}}=7 \mathrm{~cm}, \mathrm{~d}_{\mathrm{L}}=5 \mathrm{~cm}, \mathrm{Uo}=4 \mathrm{~cm} / \mathrm{s}\right)$

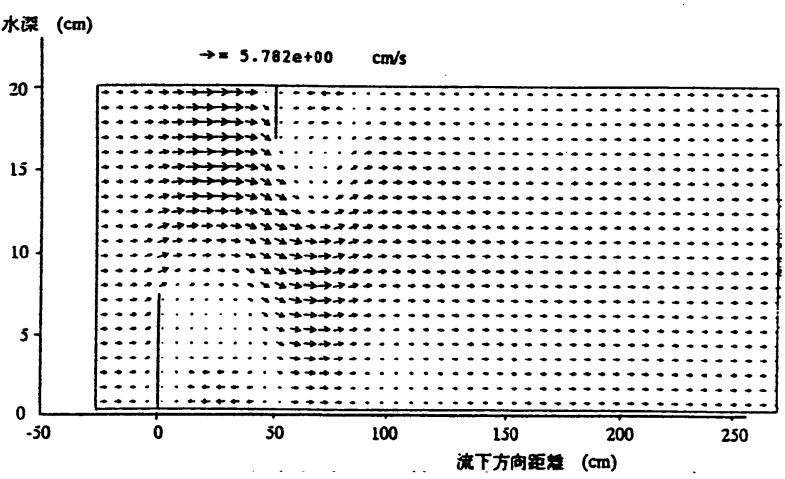

図-6 複列配置の膜周辺の流速分布の計算結果 $\left(\mathrm{d}_{\mathrm{U}}=7 \mathrm{~cm}, \mathrm{~d}_{\mathrm{L}}=5 \mathrm{~cm}, \mathrm{UO}=4 \mathrm{~cm} / \mathrm{s}\right)$ 
が形成され再び上昇流が発生することなど定性的な 流況は計算結果でも再現できている.

\section{（2）乱れ強度の分布特性}

污濁防止膜の污濁防止効果の一つとして膜端部か ら発生する乱れによる污濁拡散効果が考えられる. 図-8,9にそれぞれの設置方法で污濁防止膜を設置し た場合の乱れ強度の分布の実験結果を示す．乱れ強 度は時間平均された水平及び鈶直流速からのそれぞ れの流速時系列の残差の 2 乗平均值で定義する. ま た，比較のため防止膜を配置していない場合の乱れ 強度の分布の実験結果を図-7に示す．防止膜を設置 しないケースにおいても多少の乱れ強度が存在して いる。この乱強度と比較すると防止膜を設置した 両ケ一スとも, 自立式上端部から上方あるいは垂下 式下端部下方での乱れ強度は大きいことがわかる。 特に複列の場合は, 垂下式下端部から下流側の下層 での乱れ強度が大きく, 乱れ強度の空間分布だけを 比較してみると自立式単体の場合よりも複列式の方 が広い範囲で大きな乱れが発生していることがわか る. また, 污濁防止膜周辺の大きな乱れ強度は膜設 置位置から上下流側に離れるに従って小さくなって おり，上流側へも乱れが伝達されている.

污濁防止効果は, 防止膜背後の死水領域の形成と それによる污濁のトラップ効果に関しては, 自立式

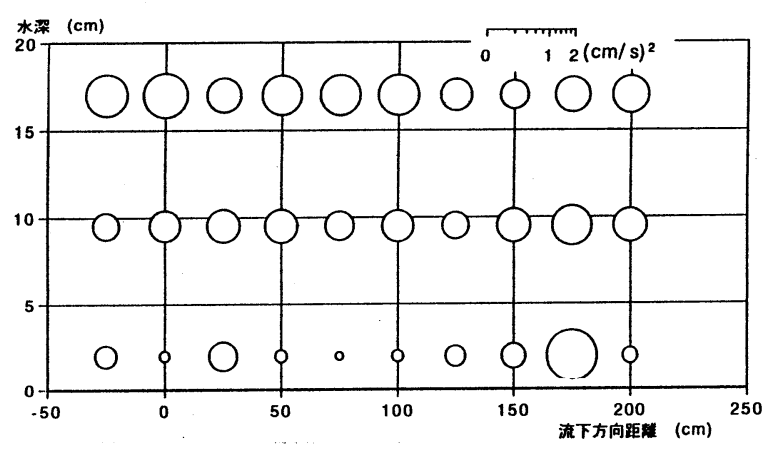

図-7 膜を設置しない場合の乱れ強度の分布 $(\mathrm{UO}=4 \mathrm{~cm} / \mathrm{s})$

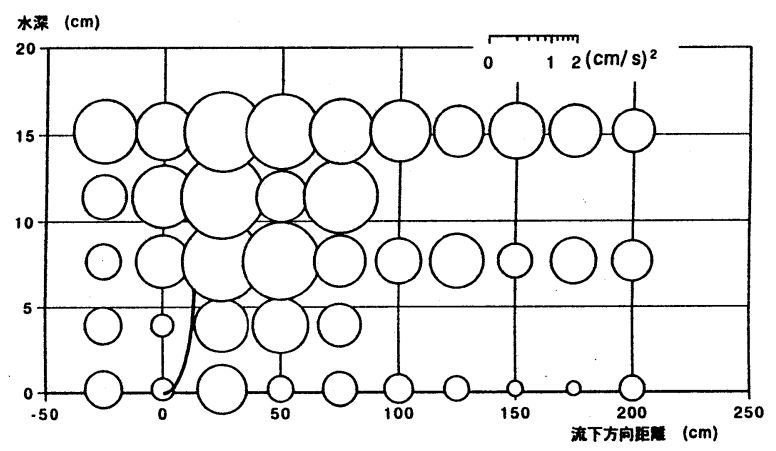

図-8 自立式単体の膜周辺の乱れ強度の分布 $\left(\mathrm{d}_{\mathrm{U}}=7 \mathrm{~cm}, \mathrm{Uo}=4 \mathrm{~cm} / \mathrm{s}\right)$

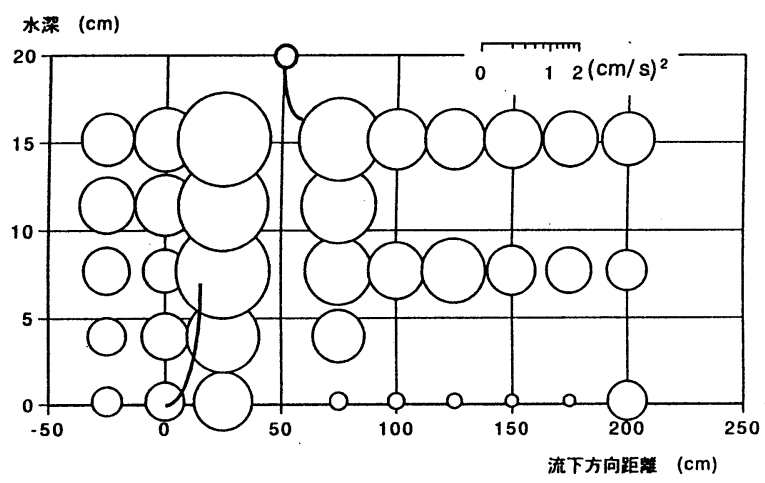

図-9 複列配置の膜周辺の乱れ強度の分布 $\left(\mathrm{d}_{\mathrm{U}}=7 \mathrm{~cm}, \mathrm{~d}_{\mathrm{L}}=5 \mathrm{~cm}, \mathrm{UO}=4 \mathrm{~cm} / \mathrm{s}\right)$

単体の方が効果があると考えられる．しかし，膜端 部から発生する乱れによる污濁拡散効果については 乱れ強度の分布が広い範囲に及ぶ複列の場合の方が 有効であると考えられる. どちらの配置法が污濁防 止効果に有効かは種々の現象の影響を総合的に比較 検討する必要がある.

\section{5. 囲い込みによる平面的な流況制御の特性}

\section{（1）平面的な流速場の特性}

図-10は一例として膜長 $\mathrm{d}_{\mathrm{U}}=7 \mathrm{~cm}, \mathrm{~d}_{\mathrm{L}}=5 \mathrm{~cm}$ の複列 式で囲い込み長さ $4 \mathrm{~m}$, 囲い込み幅 $1.5 \mathrm{~m}$ に平面配置 したときの囲い込み領域周辺の平面的な流速場の

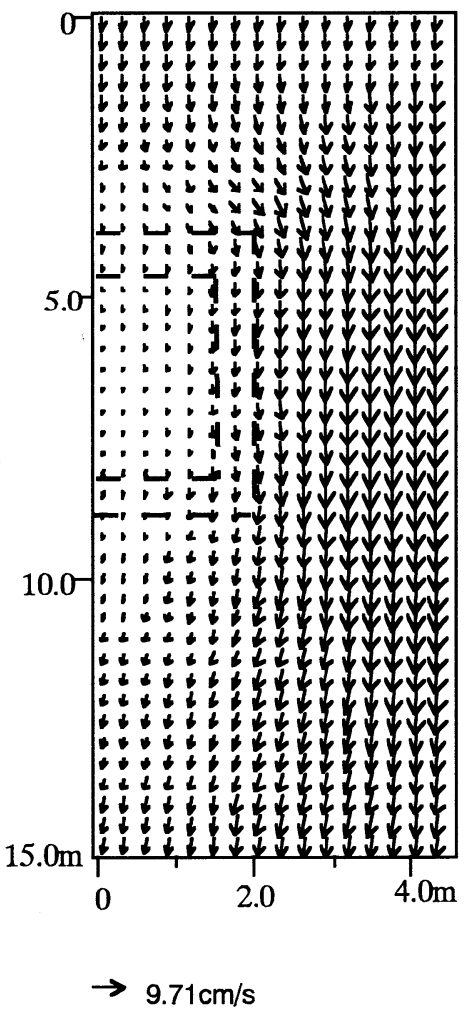

図-10 囲い込み周辺の平面的な流況(Case:E-8) $\left(\mathrm{d}_{\mathrm{U}}=7 \mathrm{~cm}, \mathrm{~d}_{\mathrm{L}}=5 \mathrm{~cm}, \mathrm{Uo}=4 \mathrm{~cm} / \mathrm{s}\right)$ 
表-1 囲い込みによる流速低減効果の実験ヶース

\begin{tabular}{|c|c|c|c|c|c|}
\hline \multirow[t]{2}{*}{ 実験ヶース } & 内側膜長 & 外㑡膜長 & 設置間隔 & 团い込み長さ & 囲い込み幅 \\
\hline & $(\mathrm{cm})$ & $(\mathrm{cm})$ & $\mathrm{d}(\mathrm{cm})$ & $\mathrm{D}(\mathrm{cm})$ & $W(\mathrm{~cm})$ \\
\hline$E-0$ & $\begin{array}{l}\text { 無し } \\
\end{array}$ & 無し & & & \\
\hline$E-1$ & 自立式7 & 無し & & 400 & 100 \\
\hline$E-2$ & 自立式7 & 無し & & 400 & 150 \\
\hline$E-3$ & 自立式7 & 無し & & 400 & 200 \\
\hline$E-4$ & 自立式7 & $\begin{array}{l}\text { 無し } \\
\end{array}$ & & 600 & 150 \\
\hline$E-5$ & 自立式10 & $\begin{array}{l}\text { 無し } \\
\end{array}$ & & 600 & 150 \\
\hline$E-6$ & 垂下式10 & $\begin{array}{l}\text { 無し } \\
\end{array}$ & & 400 & 150 \\
\hline$E-7$ & 自立式7 & 垂下式5 & 0 & 400 & 150 \\
\hline$E-8$ & 自立式7 & 垂下式5 & 50 & 400 & 150 \\
\hline$E-9$ & 自立式7 & 垂下式5 & 100 & 400 & 150 \\
\hline$E-10$ & 自立式7 & 垂下式5 & 50 & 600 & 150 \\
\hline$E-11$ & 垂下式5 & 自立式7 & 50 & 400 & 150 \\
\hline$E-12$ & 自立式10 & 垂下式5 & 50 & 600 & 150 \\
\hline
\end{tabular}

計算結果を示す．污濁防止膜を平面的に設置するこ とにより，流れは污濁防止膜で囲い込まれた領域外 を流れ，囲い込まれた領域内の流速が低減している .この流速低減効果により, 囲い込夕領域内で発生 する污濁の移流速度が低減するために污濁の流出を 低減できると考えられ，污濁防止膜を平面的に配置 した場合の有効な污濁流出低減効果と考えられる.

\section{(2)囲い込みによる流速低減効果}

図-11は，表-1に示す各実験ケースの流速低減効 果を示す. 流速低減効果は, 囲い込み領域内の断面 平均流速/断面平均流速で計算した。図より，自立 式のみを設置した場合(E-1〜5)でも $60 \%$ 程度の流速 低減効果があることがわかる．また，当然の事なが ら, 膜長が長いほど流速低減効果が大きい.

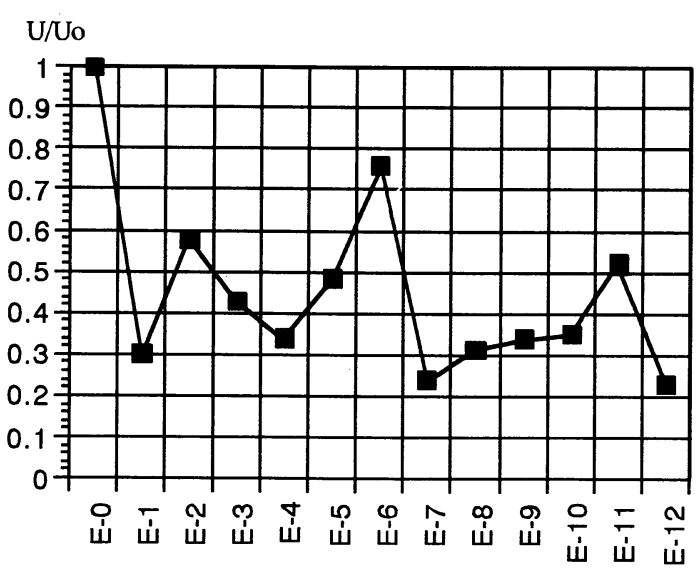

図-11 囲い込みによる流速低減効果

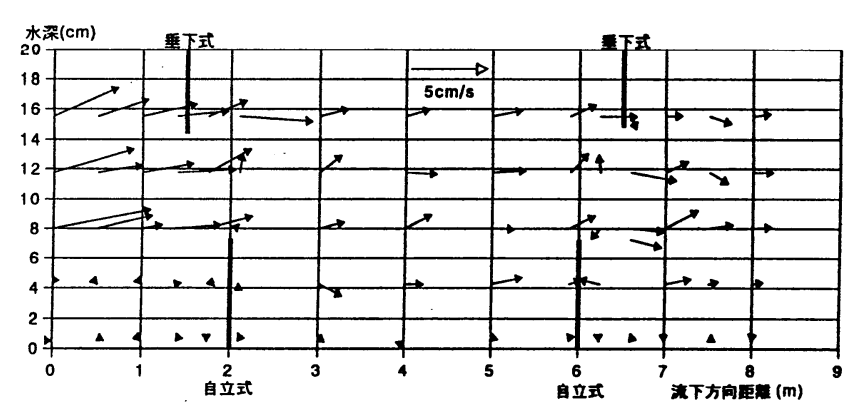

図-12 囲い込夕領域内の流速分布(Case:E-8) $\left(\mathrm{d}_{\mathrm{U}}=7 \mathrm{~cm}, \mathrm{~d}_{\mathrm{L}}=5 \mathrm{~cm}, \mathrm{UO}=4 \mathrm{~cm} / \mathrm{s}\right)$

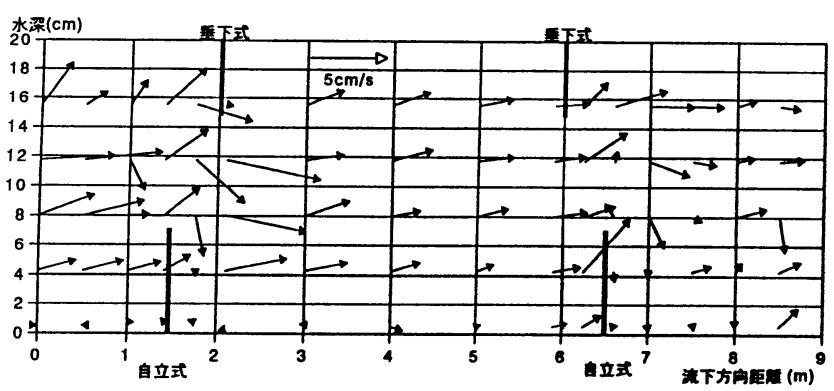

図-13 囲い込み領域内の流速分布(Case:E-11) $\left(\mathrm{d}_{\mathrm{U}}=7 \mathrm{~cm}, \mathrm{~d}_{\mathrm{L}}=5 \mathrm{~cm}, \mathrm{Uo}=4 \mathrm{~cm} / \mathrm{s}\right)$

図-12 は膜長 $\mathrm{d}_{\mathrm{U}}=7 \mathrm{~cm}, \mathrm{~d}_{\mathrm{L}}=5 \mathrm{~cm}$ の複列で, 囲い込 み長さ $4 \mathrm{~m}$, 囲い込み幅 $1.5 \mathrm{~m}$ に配置したときの囲い 込夕領域内の測点 1 に沿った断面の流速分布を示す 。また, 図-13は図-12 とは逆に垂下式を内側に自 立式を外側に配置した場合の実験結果を示す。図よ 
り防止膜を設置した近傍では流速分布の空間的な変 動は大きいが，囲い込み領域内の流速分布は空間的 に変化が少なく安定しており，流速低減効果が污濁 の移流速度の低減（囲い込夕領域内の污濁の沈降量 の増大）に効果があることがわかる．また，図一 12,13の両図を比較すると，垂下式が領域の内側に ある方が，垂下式下流部で縮流効果により流速が増 加していることがわかる．自立式が領域の内側にあ る図-12の場合は，それほど顕著に流速の増大は見 られない。これは，自立式の場合，断面縮小により 水面付近の流速は増加するが膜を設置した付近の水 面も上昇し，これが囲い込みを回り込む流速を引き 起こすのに対して，垂下式の場合は断面縮小により 海底付近の流速が大きくなっても, 海底面は固定境 界なので縮流による流速の増加が大きいものと考え られる。図-11において流速低減効果が最も少ない 実験ケースが垂下式のみを設置したケースで，75\% の流速低減効果しか得られないのも同様の理由と考 えられる。

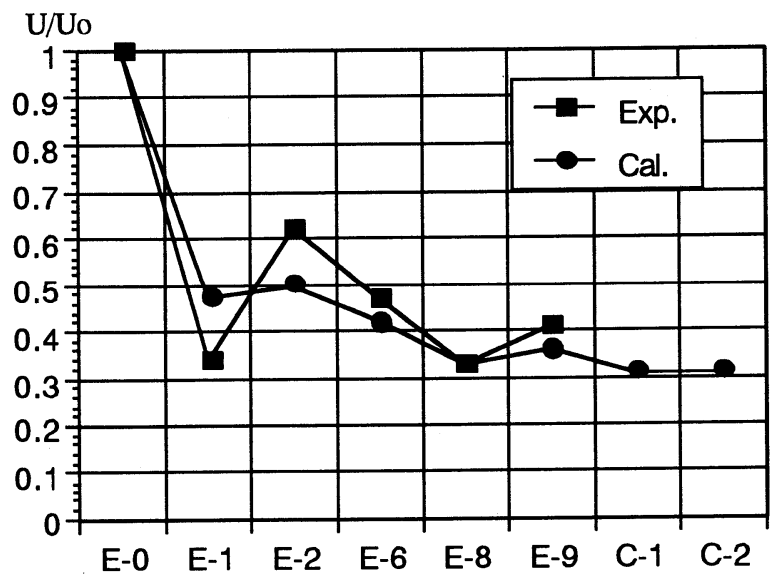

図-14 流速低減効果の実験結果と計算結果の比較

図-12,13の囲い込み領域内の流速分布を見てみる と底面摩擦の影響が大きいと考えられるので, 底面 から $4 \mathrm{~cm}$ 以下の流速を無視して囲い込夕領域内の平 均流速を定義し直して計算結果と比較した. 図-14 は囲い込みによる流速低減効果の実験結果と計算結 果との比較を示す．また，計算によりE-2の膜の配 置法で水槽幅が $9 \mathrm{~m}$ の場合 $(\mathrm{C}-1)$, 半無限大の場合 (C2)も計算を行った。図より計算結果と実駼結果は良 い一致を示す．また，囲い込み幅の 3 倍以上の幅の 水槽を用いることで, 水槽幅の影響は流速低減効果 にはそれほど影響が大きくないことがわかる.

\section{6. 結論}

本研究では, 海洋工事に伴う污濁発生に対して, 周辺海域への污濁の流出を防止するために設置され る污濁防止膜による流況制御特性について検討を行 った，得られた結果は，以下の通りである.

(1)污濁防止膜背後の死水領域の範囲など，防止膜周 辺の渦流れをSOLA法を用いた本計算方法で精度良 く予測することができる.

(2)污濁防止膜の污濁防止効果に関係すると考えられ る防止膜背後の死水領域は, 自立式を設置しその下 流側に垂下式を設置する複列式の場合, 自立式単体 を設置した場合と比較すると垂下式の影響により死 水領域は小さくなる。しかしながら, 複列式の場合 の方が自立式を流下してからの下降流が大きく, 移 流経路が長くなるため污濁の沈降効果，あるいは移 流拡散効果に自立式単体よりも有効であると考えら れる. 従って, どちらの設置法が污濁防止効果に有 効かは種々の効果を総合して検討する必要がある.

(3)污濁防止膜の污濁防止効果の一つとして膜端部か ら発生する乱れによる污濁拡散効果が考えられる. 自立式単体, 複列式の両ケースとも, 自立式上端部 から上方あるいは垂下式下端部下方での乱れ強度は 膜を設置しない場合に比較して大きい。乱れ強度の 大きさを比較してみると両ケースはほとんど変わら ないが，空間分布を比較すると自立式単体の場合よ りも複列式の方が広い範囲で乱れ強度が大きい.

(4)污濁防止膜を平面的に配置することにより, 防止 膜設置区域内で流速の低減が生じる．この流速低減 は, 防止膜設置区域内で発生する污濁に対して移流 速度を低減させ，污濁沈降量の増大に効果があるも のと考えられる.

(5)囲い込みによる流速低減効果は自立式単体の場合 でも, 膜を設置していない場合の流速の半分程度は 低減できる. また, 単層モデルを用いて囲い込みに よる流速低減効果はほぼ予測できることがわかる。

\section{参考文献}

1) 小田一紀・重松孝昌 他: 污濁抎散防止膜周囲の 鈆直 2 次元流れに関する実験的研究,海岸工学論 文集 第38巻,pp.876-880,1991.

2)高橋亮一 編著 : コンピューターによる流体力学 <演習>，（株）構造設計研究所, $275 \mathrm{p}, 1982$.

（1999.4.19受付） 